\title{
Horse and Carriage? Megachurches and Revivalism
}

\author{
Stephen Hunt
}

\section{1 \\ Introduction}

There are perhaps strong arguments buried in the conjecture that, much like love and marriage and the proverbial horse and carriage, there is an inseparable reciprocal relationship between contemporary megachurches and the tradition of Christian revivalism. In short, that such churches have habitually grown when underscored by the oft pragmatic imperative, embraced by their leadership at least, of enduring and constant revival. It is an imperative embellished by the cultural ethic that 'big is beautiful', 'big is good', and the conviction that revival is a key instrument for the realisation of these ideals in the religious sphere. Yet the envisaged co-joining remains problematic for several underlying reasons. Firstly, linking the megachurches and revivalism essentially depends on precisely what is meant by 'revival', especially within the distinct context of the emergence of the megachurch phenomenon. Secondly, that some features of the megachurch concerned with increasing congregational growth by providing a 'safe space' for potential converts and especially active 'seekers' in a highly competitive so-called 'spiritual marketplace' would seem to mitigate in some respects against the cause of revival with all of its emotionalism, collective dedication, and spiritual intensity. In particular, that the 'unsaved' are not initially attracted to a church which appears to be threatening in terms of pressurising 'seekers' to conform to a rigorously strict and demanding form of religious life that 'revivalism' suggests. Thirdly, evidence of megachurch 'revivals' implies that they are not exclusively related to seeking converts and boosting the ranks of the faithful. Rather, revivals may have more of a function of 'refreshing' and retaining extant members and even constitute part of the church-switching phenomenon which is an integral part of the spiritual marketplace.

In the light of these considerations, this chapter ponders the apparent centrality of revivalism to the success or otherwise of the megachurch or, more precisely, one distinctive brand of megachurch: those of a Pentecostal or Charismatic (neo-Pentecostal) genre which have experienced a considerable influence on the megachurch movement. At first glance this emphasis might appear to be unfounded since, according to the Hartford Institute of Religious 
Research, only some 5 percent of megachurches are of Pentecostal persuasion. That acknowledged, to the list can be added, suggests the Institute's research, some further 5 percent which are Charismatic - 'classical' Pentecostalism's highly influential outcrop that emerged from the 1960 and which subsequently developed as a number of unique but over-lapping 'streams'.

The distinction between Pentecostal/Charismatic and other types of megachurches however is hardly straightforward given that even those claiming not to be of this theological persuasion share, according to the 2011 Bird and Thumma survey, some essential similarities given that the majority of megachurches were found to embrace "a high view of their own spiritual vitality" and an overwhelming 98 percent agreed that their congregations were "spiritually alive and vital" - the kind of rhetoric mostly associated with 'spirit filled' churches of a Pentecostal/Charismatic nature and which resonates as an element of the language of 'revival'. It may be conjectured, then, that the culture, theology and praxis of the Pentecostal/Charismatic evangelical strand has, in fact, impacted megachurches which do not necessarily claim to be of such a genus.

This chapter commences by considering the nature of revivalism and then proceeds to consider the centrality of revivalism to the Pentecostal/Charismatic tradition and its wider influence, exploring the relationship with church growth philosophies and the emergence of the megachurch. And, moreover, the chapter seeks to discuss the discernible connection between that tradition and the dynamics of modernity which underpin these churches. The chapter concludes by considering the more recent revivals and, as flagged up briefly above, of the specific impact of revivalism on church growth in the spiritual marketplace.

\section{Revival, Revivalism and Modernity}

The term 'revival' is one which frequently forges excitement and emotion for evangelical Christians of different persuasion. From one perspective the 'revival' is an essential part of fulfilling the renowned 'Great Commission'; that is, winning converts as accounted in the biblical record where Jesus instructed his disciples towards the end of his ministry. This is a dimension fused with millenarian hopes on behalf of the faithful of the return of the messiah to earth and the establishment of God's Kingdom. That numerous Christians of a more evangelical/fundamentalist preference have linked this to expectations of a great future revival and 'winning of souls', where the mission field would be 'white unto harvest', is more than evident in past and recent revivals. 
The nature of revivalism, and indeed how it might be defined, is somewhat more complex than this simple appraisal might indicate. Revival is an exhilarating word within the Christian lexicon. It evokes visions of the new life wrought by redemption, the active power of the Holy Spirit, renewal and restoration, and the promise of hope for the future. The reality however is that revival is a diverse, multifaceted, and frequently controversial religious manifestation. This is well-emphasised in Walker and Aune's introduction to their edited volume, On Revival (2003), where they query whether Christian revivalism is a wider culturally-bound religious phenomenon largely produced in the Western context, or a more narrowly biblically-based one founded on certain Christian scriptures. Moreover, is there a difference between a 'revival' and a 'renewal' - the spiritually of believers and the Church, constituting a 'time of refreshing' for the faithful? Some recent major revivals (considered below) involve both and confirm that revivals are, more often than not, multidimensional in nature.

Taking the subject even further, Steve Latham's chapter in the same volume additionally nuances the differences between 'revival' and 'revivalism', identifying various levels of what is often called 'revival', ranging from a (spiritual) 'quickening' of the individual believer in their faith, to the full-blown reversal of secularisation of society through mass conversions, to increased spiritual interest or renewal in the life of a church congregation with perhaps a local, national or global impact. Revivals can be also seen as the broader revitalisation of the universal Church to what is perceived as a vital and fervent relationship with God following a period of moral decline (Latham 2003). All of these interpretations of 'revival' should clearly be distinguished from the largely 'in-house' evangelical use of the term 'revival' to refer to an evangelistic meeting or series of meeting organised to galvanise the faithful and 'win souls'.

In the form of mass conversions of non-believers, revivals are often viewed by church leaders as having positive moral effects for their congregations and potentially, at least, wider cultural consequences. In this way the concept of revival is derived from biblical narratives of national decline and restoration during the history of the Israelites as a result of collective sin and cycles of national revival associated with the rule of various righteous monarchs. In turn, of a more academic hue, Church historians have identified and debated the effects of various national revivals within the history of the USA and other countries. During the eighteenth and nineteenth centuries American society experienced a number of 'Awakenings' around the years 1727, 1792, 1830, 1857 and 1882 (McClymond 2004). The revivals in the first decades of the twentieth century, several with roots in some of the earlier revivals, included those of the 
1904-1905 Welsh Revival and the 1906 Azusa Street Revival in Los Angeles that is associated with the emergence of the Pentecostal movement. To this can be added the mid-century revival in the form of (Charismatic) 'Renewal' of the mainstream denominations, as well as the forging of independent ministries and churches of which the megachurch phenomenon was a further element.

Do the particular datings of these 'Awakenings' and periods of revival suggest movements fundamentally reactionary in nature, resisting aspects of modernity and secularity, and amount primarily to attempts to win converts and rejuvenate the spirituality of the faithful? The picture is complex. In an earlier contribution to the subject, Andrew Walker (1997) pulled attention to the connection between revivalism, especially in its Pentecostal/Charismatic mode, to modernity and much of what it entails by way of a world-accommodating ethos. This is an observation which, on initial consideration, seems to be counter to common sense understanding of modernity's rejection of religion since such revivals were historically fused with a belief in the supernatural and 'signs and wonders' as the essential 'proofs' of that supernatural - prophetic utterances, claims to divine healing, glossolalia and so on associated with 'primitive' forms of ecstatic and esoteric Christianity (Cox 1996). None of this would seem to equate with the Enlightenment's preoccupation with rationality, secularity and utilitarianism.

Pentecostalism, and its Charismatic derivative proved, according to Walker (1997: 19), to be the most successful embodiment of revivalism in the present age. Yet he points out that revivalism, as a broad religious occurrence, itself came into existence at the commencement of the Enlightenment and can be understood as essentially "thoroughly modern". Walker's analysis of the history of revivalism leads him to conclude that the early revivals during this period not only stressed piety but individualism and rationalism: "The Age of Reason was also the age of revivals". Leaders of revival in the eighteenth century, such as John Wesley and Jonathan Edwards, were admirers of science; the latter influenced in his thinking by the likes of John Locke and Isaac Newton. The First Great Awakening (1730s-1740s) in New England where by adherents to Protestantism strove to renew individual piety and religious devotion, Walker relates, was part of the cultural transferal from feudalism to capitalism. In advancing his argument Walker conjectures that the most convincing evidence of the modernising tendencies of early revivalism comes from Jon Butler's (1990) revisionist accounts of the American Awakenings (especially the Second Awakening at the advent of the nineteenth century which was essentially a Protestant revival led largely by Baptists and Methodists) where he demonstrates that the passion and piety of the revivals also fuelled the progressivist vision of the American dream infused by the conviction of the virtues of the ethic of 
equality of opportunity, allowing the highest aspirations, potential and goals to be realised.

Walker continues his analysis by arguing that the early revivals generated unintended consequences, not least of all because their emphasis on experience and the self were profound in the sense of encouraging individualism. Yet it was also conducive both to the religious freedom of the United States Republic and to the pietistic but theologically non-specific 'civil religion' of middle America with all of its sacred symbols bringing social and cultural integration through the belief in the 'Manifold Destiny' and dedication to the virtues of liberty, individualism, and hard endeavour for self-advancement. More obviously, revivals were themselves aided both by the technology and the principles of modernity (Walker 1997: 19-20). Walker writes of the consequences of this for orchestrated revivals, an observation that was to be particularly relevant with late twentieth-early twenty-first Pentecostal/ Charismatic revivals:

Not only is this the case with the appropriation of firstly the telegraph and later the phonograph for the more routinized revivals and urban missions of the nineteenth century, but it is also the case that revivalists came to see their campaigns in terms of pragmatic techniques.

WALKER 1997: 20

Walker goes on to state that

... The first revivals were too new, spontaneous and unexpected to be honed into a technique. But the assertion does not hold for Finney's great revivals of the early years of the nineteenth century. As he says in his Lectures On Revival: 'A revival is not a miracle, or dependent on a miracle, in any sense. It is purely philosophical result of the right use of constituted means as much as any other effect produced by the application of means. ${ }^{1}$

The early revivals, for Walker, contributed to the advancement of modernity because they provided, in his words, "... a value matrix conducive to the ascetic Protestantism of early capitalism. The enthusiasm, freedom, individualism and moral values of the revivals entered the mainstream of American society" (Walker 1997: 20). Pentecostalism, as a powerful mechanism for revival, did not escape this development. Walker (1997:21-22) explains that the later Pentecostal revivals of the early twentieth century were apparently even less candidates

1 Quoted in J. Seel's “Modernity and Evangelicals” (1994, 293). 
for carriers of modernity than those which predated them. The early Pentecostals, through their pre-millenarian theology, were convinced that the end of the world was on the horizon and the Kingdom of God imminent. Moreover, Pentecostalism revival was itself seen by its adherents of the confirmation of the End-Days before the return of Christ. Such a conviction spurred worldwide evangelising missions, initially void of the concern to build churches of any substance.

However, over time, as Walker insists, the Pentecostals became at least "an unwitting symbolic carrier of modernity as well as falling under the spell of secularising tendencies of the modern world", although the response has varied between 'classical' and neo-Pentecostals and those in the developed and developing world. Walker (1997: 26-27) explores how, over time, Pentecostalism trod the well-worn path of earlier urban missions in the USA with all their pragmatic tendencies and awash with the latest modern technologies, advertising, management techniques, entrepreneurship, and theological colleges for training ministers for their growing churches as an organisational basis for foreign mission fields. Neither were such developments limited to the Western world. Walker points to David Martin's (1990) studies of the modernising tendencies of Pentecostalism in many nations with Christian traditions and amount to 'emerging economies'. This variety of evangelical Christianity came, towards the end of the twentieth century, to be the fastest growing form of the faith in nations with rapidly expanding capitalist economies, making particular inroads in Central and South America where the movement's leaders are not only Spirit-led but also leading politicians, entrepreneurs and small businessmen.

In discussing the emergence of the neo-Pentecostals (otherwise known as the Charismatic movement) Walker (1997: 29-30) notes how Pentecostalism had become attractive especially to the middle classes. It was in an era moving from early to late modernity; where the advent of consumerism in the $1950 \mathrm{~s}$ saw the demise of ascetic individualism and the rise of hedonistic individualism concomitant with a consumer economy. Such an appraisal resonates with a recognition, albeit indirectly, of some of the ethics and alluring characteristics of the megachurch in the spiritual marketplace, but there is more which fused Pentecostalism in its various forms with the culture of such churches, even if not exclusively so.

The gentrification of Pentecostalism, argues Walker, proved to be phenomenologically identical to being a Pentecostal but culturally redefined by class, tastes and the late modern preoccupation with therapy, self-fulfilment and self-expression. It was in the 1970s and 8os that revivalist figures such as Jimmy and Tammy Baker rejected their strident fundamentalism and adopted 
"a folksy, cosy approach". It was a time when tele-evangelism, with all of its revivalistic tenor, reflected the narcissistic streak of modern American hedonism (Walker 1997: 30). From the late 1970s, during the heyday of the so-called Charismatic Renewal, there occurred the emergence of numerous independent ministries, maverick organisations, new networks of churches, and parachurch groups. There is no coincidence that it was during this era that megachurches began to proliferate in some number. Whether the revivals involved then and since has amounted to a significant quantity of new converts is questionable.

Walker's observation that the excitement and novel outlandish experiences of the period was not solely due to the spirit of revivalism also stands for the apparent success of the megachurch. He writes: "Charismatic growth has resulted primarily through recycling Christians from one denomination to another, or renewing pockets of established denominations and sects" (Walker 1997: 34). While such 'recycling of the saints' can be identified as part of the growth and endurance of the megachurch, revivals were nonetheless at least potentially capable of winning over large numbers of people which led to the establishment of churches with sizeable congregations or even, in time, the creation of new denominations.

\section{3}

\section{Historical Revivals}

As Martyn Percy (in this volume) points out, the megachurch movement as it is understood today has arguably precedents in many of the vast Protestant congregations of the nineteenth and early twentieth centuries, born of revival and capable of growing particularly rapidly during times of revivalism in the usA. Typical, Percy suggests, was the Moody Church of Chicago which sustained megachurch status longer than any other American church (from 1876 to the present). Certainly, as Percy advances, the church's connection with the Moody Bible Institute has been important, but there have been many other churches tied to colleges that have declined or ceased to exist. In the past such churches were linked to revival and revival was always about winning souls as well as spiritually reinvigorating the faithful.

Previous to the emergence of Pentecostalism, probably the most vibrant form of global contemporary evangelicalism, movements of revivalism and renewal had come and gone throughout two thousand years of Christian history with some frequency, although their expression and form, as well as their impact on the wider socio-cultural environment, varied considerably. It may also be said that socio-cultural environments also helped generate such revivals, not least of all secularising impulses to which revivalistic missions at least 
partially reacted. Periods of revivalism by their very nature quickly evaporated, but the sects spawned in their wake often endured for appreciable lengths of time. Other periods of revivalism rapidly dissipated, frequently reduced to mere footnotes in religious history.

Whatever their duration, more often than not these revivalist movements displayed similar characteristics (see for example, Knox 1961). Recurrently exclusively sect-like in nature, such movements typically broke away from established denominations, dismissed them as corrupt, worldly, and heretical (a compliment often returned by the churches from which they seceded). Typically, these sectarian crusades saw their own emergence as signifying the return to New Testament principles - a claim often accompanied by reference to fresh divine revelations forged within an eschatological vision of restoring the 'true' faith. Over time, as in the case of the Methodist revival of the eighteenth century led by John and Charles Wesley, revivalist movements, if they did not entirely disappear from Church annals completely, settled down to become large denominations of some note throughout the British Empire, the USA and beyond as a result of vigorous mission work.

Many of these processes of sectarian development seemed to characterise the evolution of several principal strands of 'classical' Pentecostalism. At the beginning of the twentieth century, the revivalistic movement went on to attract hundreds of thousands of followers with a distinct form of Christianity. Largely, in patterned sectarian development, it was ostracised by the mainstream churches. Thus, Pentecostalism carved its own way in the world. Over a relatively short period however, the movement was to forge institutional structures of its own and to the extent that many of its sectarian expressions gave way to denominational forms in much the same direction as previous revivalistic movements had done.

The precise initial origins of Pentecostalism are open to much debate. Events at the Azusa Street revival (1906), in Los Angeles, rightly have their venerated place in the history of Pentecostalism, not least of all because clergy of different traditions visited the Azusa mission and took the revivalistic spirit back to their own churches. The selected emphasis on one particular episode has however, tended to obscure the fact that the momentum for an apparently fresh version of ecstatic Christianity had already occurred in several places in the USA and elsewhere in the world and, as it were, prepared the way for fullblown Pentecostal-style revivalism (see Allan Anderson (2004) for the historical details). The exact roots of its emergence in the USA, especially its foundations in early revivalist movements such as those of Methodism and Holiness meetings, need not concern us here however. 
From the 1906 to 1909 the USA South became the first region in the world where Pentecostalism put down deep roots and significantly changed the spiritual landscape of a nation not unaccustomed to 'great awakenings'. The movement spread to the South-West and Mid-West, then beyond those regions. As a religion largely of the 'disinherited' (R.M. Anderson 1980) it found futile soil among the impoverished and where both blacks and whites struggled for subsistence on the margins of society. It was in the USA that the first Pentecostal denominations in the world, including the Church of God in Christ, the Pentecostal Holiness Church, the Church of God and the Assemblies of God, went on to enjoy an extraordinary appeal. Indeed, in the decade that followed the southern Pentecostal groups emerged to play major roles in developing the ethos and character of the movement.

These denominations also forged some of the largest individual megachurches in the USA. Today, the Hartford Institute's database lists more than 1,300 megachurches in the country. According to that data, approximately $5^{0}$ churches on the list have attendance ranging from 10,000 to 47,000. Those of a Pentecostal persuasion are well-represented among these groups taken at random from the list and include Calvary Chapel Fort Lauderdale (FL) - 30,0oo; City of Refuge; First Assembly of God (Fort Myers, FL), Pentecostal Assemblies of the World - 10,000; James River Church (Springfield, MO) Assembly of God - 14,000.

From an early stage the Pentecostal movement extended rapidly across the world, forming churches in countries where Christianity already had a foothold. And, as a revivalistic movement, spread to fresh fields through missionary endeavours which often put down roots for some of the largest megachurches in the world, a fair number of which associated with Pentecostal denominations or other bodies founded in the USA including Yoido Full Gospel Church, Seoul, Korea $(253,000)$ associated with the Assemblies of God; Elim Church, San Salvador, El Salvador (117,00o); Assemblies of God Grace and Truth, Kyanggi-do, South Korea (105,000).

\section{4}

\section{Renewal}

Renewal movements or 'revivals' within the more established or 'mainstream' churches, as Pousson (1994) explores, are far from new. He notes that by the end of the nineteenth century practically all Christian denominations throughout the Western world, including Orthodox, Catholic and Protestant, had been 'renewed' in one way of another. Those representing Protestantism during this 
period included Pietism, Puritanism, Moravianism, the Evangelical revival in England and the related Wesleyan revival and the Great Awakenings in the American colonies, several of which laid the grounding for Pentecostalism. In turn, during the mid-twentieth century, a number of principal Pentecostal bodies established dialogue with the historical churches, and from this initiative neo-Pentecostalism in the shape of the Charismatic Renewal movement was seemingly born as the established denominations opened themselves up to the theology (such as Baptism in the Holy Spirit) and praxis (healing, prophecy, glossolalia etc) of Pentecostalism.

Using the UK as an indicator of the success of neo-Pentecostalism, the context of renewal led to Charismatic churches from the 196os into the 1990s becoming the highest proportion of growing churches over a period in which church attendance was generally on rapid decline (Brierly 1991: 131, 153). Renewal was also responsible for the emergence of some of the largest churches in the country during this period, a number of which could be described as 'mega'. Miller (adopting the term 'New Paradigm Churches') gives the example of St. Andrews church in Chorelywood, and Anglican congregation, and its connection with the nationally organised New Wine Christian convention (Miller 1997: 115). Such churches then (and now) were in reality few and far between. Nonetheless, at the time they were frequently regarded as an ideal model for church growth and churches of a greater size were, for a season at least, growing at the expense of more traditional forms. The organisational dynamics and range of attractions of the megachurch were discernible in such congregations. The majority were of a Pentecostal/Charismatic disposition.

To these churches, at the time, were added a relatively small number of UK megachurches located in the more traditional Pentecostal denominations. Much was typified by Kensington Temple, London, of the Elim denomination, often assumed to be the largest congregation in the country with its predominantly black ethnic congregation. Within a few years 'KT', as it was known, came to be matched by other Charismatic megachurches. This included the Abundant Life Church in Bradford, northern England. Withdrawing from the Covenant Ministries, a large 'New Church' 'stream', the ALC in the late 1990s could claim 2,500 attendees at its Sunday services. The broadcasts of its international Charismatic ministry reached over 150 countries. A similar church (with an attendance of 2,300) was the Renewal Christian Centre in Birmingham which was associated with the Free Methodist Church in the UsA. While the size of such congregations hardly matched that of many megachurches in North America, in the context of a largely post-Christian UK, these were on an impressive scale.

The development of an increasing number of Charismatic 'streams' in the UK was reflected in similar developments in the USA - often in the form of 
New Paradigm Churches, regarded by Donald Miller (1997) as a fresh 'reformation', with an emphasis on revivalism and church growth, not infrequently leading to the founding of megachurches. Much has been exemplified by the Association of Vineyard Churches and its centrality of church-growth strategies, not to mention its emphasis on personal conviction, spiritual experience and variations of 'Christianised' therapeutic techniques which were all in integral part of what became known as the 'neo-Charismatic' movement and which perhaps was best remembered for its emphasis on 'signs and wonders' that became a unique form of ministry its own right.

Classical Pentecostalism was born to a large extent in the milieu of an increasingly relentless culture of disbelief and scepticism. It is not surprising then, that the early Pentecostals were subject to the scorn of a secular world. Moreover, as already acknowledged above, they were ostracised by the Christian establishment whether liberals or conservatives. The Pentecostals were marginalised not merely because they were 'new' or 'different', or even because of their emotionalism and ecstatic manifestations, but because they sought the reality of the supernatural through miraculous healing, prophecy, demonic deliverance and so on. Such manifestations, the 'proofs' of the reality of God, became central to Pentecostal 'signs and wonders' that accompanied mission and revival.

Throughout the Charismatic movement, as it grew to significance in the early 196os, notions of signs and wonders were far from absent. The neoCharismatics, a new wave of renewal in the 199os and typified by the Association of Vineyard Churches - a network of churches emerging in the USA and then spreading globally - began to take signs and wonders to their furthest conclusion. The ministry of John Wimber, leader of Vineyard, epitomised the ministry, while Peter Wagner and others at Fuller seminary articulated the theological direction in terms of church growth strategies. Wagner, in turn, was influenced by the writings of Donald McGavran well-known for his advocacy for church growth through the 'homogeneous unit' principle which claimed that converts could be won by attracting them to churches comprised of congregations of people from similar backgrounds, a strategy not lost on the developing megachurch movement (Hunt 2009a: 397-402). For Wimber, as with Wagner, a reading of the history of the great revivals of the past showed conclusively that converts were won through the 'proofs' of signs and wonders such as miraculous healings. 'Equipping the saints' of today, argued Wimber, meant teaching the faithful how to call on God for signs and wonders in preparation for future revivals. Here the belief in the reality of supernatural manifestations meet the pragmatism of church growth strategies. So-called supernatural phenomenon, such as healing, prophecy and demonic deliverance, became a familiar part of the Vineyard movement's ministry and evangelistic campaigns 
and in many respects to good effect by way of church growth. The Vineyard movement grew and many of its churches became congregations of megachurch proportion, displaying numerous familiar structural and cultural characteristics associated with them.

Not surprisingly, the success of Vineyard and similar organisations drew academic interest. Among them was the work of Mauss and Perrin (1992). Vineyard, so they argued, offered a convincing belief system, a sense of being caught up in a successful movement of revival, but was not particularly strict about personal lifestyles or commitment. There were the additional attractions of emotional healing, contemporary music and a middle class cultural milieu that allowed the opportunity for like to be with like in terms of social background membership. Often world-accommodating and relatively openminded on social issues, Vineyard did not insist on a great deal of theological and ethical conformity. Vineyard also thrived off the novelties which it promised its members, mostly more signs and wonders that was believed to herald revival on a huge scale. A leading figure in the Charismatic Renewal movement in the UK, the late Douglas McBain, with veiled reference to the Vineyard organisation, critically observed that

When one theme does not deliver what is expected of it, the tendency has been to drop it without further ado. But the truth is that these enthusiasms pursue each other with restless haste across a stage of the consciousness of renewal, each one concerning its predecessor with a cannibalistic ferocity pursuit of its successor.

MCBAIN 1997: 68

It was a statement itself that was to prove extremely prophetic in terms of the revivals which occurred from the 199os onwards. These revivals were often initiated in the pursuit of church growth as well as retaining church members in a competitive spiritual marketplace. Three revivals in particular highlighted this tendency: those in Toronto, Brownsville and Lakeland in the USA, which occurred over a period of about a decade. Each revival seemed to have arrived, in a short period of time, after the leadership of these churches had prayed for revival and church growth and took practical steps to bring it about with what Peter Ward (2003) has termed 'entrepreneurial revivalism', where once again in no uncertain terms the conviction of the reality of the supernatural met the pragmatism of orchestrated revivals. These were revivals encouraged and carried through by a network of prominent church leaders and charismatic (in a Weberian sense) evangelists linked by global systems of communication. 
In a sense there was much in these revivals to confirm Thumma and Bird's (2015) conviction that megachurches in the spiritual marketplace were very apt at offering a unique and customised experience through many channels that the megachurches provide.

An earlier study by Scott Thumma and Dave Travis' (2007) suggested that megachurches placed no particular emphasis on achieving their size as a 'selling point', alongside the developed personality cult centred on the leader. That acknowledge, some churches are able, if temporarily, in times of revival to reach megachurch status and emphasis the significance of numbers. Moreover, revival means, in the mind of leaders of revivals, seeking for large numbers of convert and constitute 'poofs' of God moving among the faithful. In turn, this raises interesting questions about definitions of megachurches. Churches may numerically swell during times of revival, as with those discussed below which lasted for several years, but are not necessarily able to retain the enthusiasm of revival and church attendance over a protracted period of time.

\section{Late Twentieth-Century Revivals and Beyond}

Philip Richter (1995) numbers among several academic commentators who explored the so-called 'Toronto Blessing' revival which those involved saw as both a movement for church growth and spiritual renewal of church members. It could be comprehended as a form of religious experience characterised by many unusual physical phenomena evidenced at the Airport Vineyard Church, Toronto, from 1995, a member congregation of the Association of Vineyard Churches. This included a sense of bodily weakness and falling to the ground: shaking, trembling and convulsive movements; uncontrollable laughter or wailing and inconsolable weeping; 'spiritual drunkenness'; animal sounds; and intense physical activity - as well as accompanied by such phenomenon as a heightened sense of the presence of God; 'prophetic' insights into the future and 'prophetic' announcements from God; visions; and 'out of the body' mystical experiences. Events at the church coincided with the visit of South African evangelist Rodney Howard Browne and, before that, the influence of John Wimber's 'power ministry' of signs and wonders.

The Toronto Blessing was claimed by those who led the revival to surpass earlier similar phenomena in terms of its wide geographical spread (to at least 34 of the countries apparently witness the distinctive attributes of this revival), its frequently and its intensity (Poloma 2003). Richter (1995) sees its popular 
embrace by evangelicals as predominantly a 'supply-side' orientated manifestation. He points out that it was not the first time that phenomena similar to the Toronto Blessing have been mobilised to increase market share in the religious economy at a time when Charismatic Renewal needed its own further 'renewal' (Finke and Stark 1992: 92-93).

In December 1995 the Airport Vineyard Church, whose leadership had previously prayed for revival and congregational growth, parted company with the Association of Vineyard Churches, following the AVC's withdrawal of their endorsement on the grounds that the Toronto church was not within the framework of values and ministry style of the Association. In turn, the Toronto church appeared confident of the benefits of the split since its regular attendance was reaching megachurch proportions and that events at the church amounted to a revival which would spread globally. Moreover, one of the most salient feature of the Toronto Blessing was the number of 'pilgrimages' that took place at the church from numerous countries. By June 1995 over 300,000 people had visited the church. On average Airport Vineyard Church hosted over 800 people per night since the Blessing first manifested itself. Its legitimacy, as Richter (1995: 99) suggests, was that the churches principal pastor, John Arnott, associated events with previous revivals such as that at Azusa Street, central to the birth of modern Pentecostalism, pointing out that it similarly drew huge numbers of people from all over the world. More of the same ilk was to follow.

Amanda Tellefsen and David Bromley (nd) recall how the Brownsville Revival (also referred to the 'Pensacola Outpouring') occurred within the Brownsville Assembly of God church in Pensacola, Florida. From 1993 to 1995 the leadership and the congregation had been praying for a revival in their church that was experiencing decline. The church reported prophecies of a coming revival from within its congregation and beyond. The pastor of the Yoido Full Gospel Church (Assemblies of God) in Korea (as noted above believed to be the world's largest megachurch) announced that God had said to him in 1993 there would be a revival in the city of Pensacola, and it would spread like a fire until all of the USA had been consumed by it.

It is generally agreed by those involved that the Brownsville Revival began during the sermon of guest evangelist Steve Hill in June 1996. Hill was originally asked to preach during an evening service but was later inivted by the church's leadership to speak during the Sunday morning service at which the revival manifestations reportedly began. Manifestations particular to the Brownsville Revival included shaking and jerking of the body, crying, uninhibited laughter, paralysis of the body and even brief moments of unconsciousness 
(manifestations earlier associated with the Toronto Blessing). These gifts could be transmitted to believers through touch ('impartation') by the leaders of the revival. Word quickly spread about the manifestations at the revival, and attendance at the Brownsville Assembly increased dramatically as visitors from different denominations, USA states, and countries flocked to the church. Within the first two weeks of the revival the church had temporarily at least reached megachurch proportions when approximately 10,000 people attended services, and by the end of July 1995 the revival was drawing around 4,000 visitors nightly. The revival thrived for several years, but by 1999 revival meetings were reduced to a one-night-a-week schedule as the church lost its temporary 'mega' status.

Following the Toronto and Brownsville revivals, further revivals were expected by those involved and prophesised to be accompanied by an increase of esoteric and ecstatic manifestations of the Holy Spirit. Minor revivals in fact broke out across churches in various cities of the northern United States, some of which were well-known Charismatic megachurches (Poloma 2003), before the third major revival occurred. The two men who most prominently involved in the events that became known as the Florida Outpouring (or the Lakeland Revival) were Stephen Strader and Canadian evangelist Todd Bentley (Hunt 2009b). The Carpenters and Joiners Church had earlier continued to experience membership decline and finally closed in 2005. That same year Strader established and assumed leadership of the Ignited Church in Lakeland in 2005 which initially drew membership from the then defunct Carpenters and Joiners Church.

Leading up to the outbreak of revival in Lakeland, Bentley's visit for evangelism and healing in Lakeland was initially scheduled for five days but due to his personal charisma, claims of miraculous healing, and the unusual physical phenomena observed in the church he remained for over six months. Perceived as a significant move of the Holy Spirit, the revival claimed to have attracted an estimated 140,000 people from over 40 countries by the close of May and by the end of June 400,000 from some 100 nations. This was in addition to around 1,200,000 that watched via the Internet as well as those who tuned into the broad coverage offered by GODTV. The revival was also streamed live via Ustream by the Ignited Church and received over one million 'hits' in the first five weeks of transmissions. However, as with the revivals in Toronto and Brownsville, this revival too petered out and the church which for a year or two reached megachurch proportions experienced a decline close to its original congregational membership numbers. This raises further questions of not just what constitutes a 'megachurch' but any church if defined in terms of an 
organised site of members and attendees, given that such revivals may merely temporary boost attendance and that the life of the megachurch may, in some instances, be merely limited to periods of revival.

While Pentecostal/charismatic revivals might come and go, the direct or indirect impact they have made in Protestant Christian circles nonetheless cannot be doubted. The success of Pentecostal/Charismatic megachurches did not go unnoticed by other churches of an evangelical persuasion. Their strategies for church growth, especially the revivalist element, was of particular attraction. To be sure, there were elements of classical/neo-Pentecostalism that evangelical churches in North America and Western Europe had long 'bought' into. The Charismatic Movement of the 196os persuaded not only some more traditional evangelical leaders to embrace theological and cultural innovations around the 'gifts of the Spirit' but attracted some mainline churches too. Renewal was not only about spiritual blessings but revival to win converts at a time of the decline of the conventional denominations. In addition, evangelical churches generally moved towards loose affiliations and networks through which business models for church growth could be exchanged. The revivals at the end of the twentieth century and the beginning of the next century pulled in many non-Pentecostal/charismatic evangelicals to witness the mechanic of church growth towards which revival imperative was central.

Summary: Revivalism, Megachurches and the Spiritual Marketplace

This chapter has focused on megachurches in relation to revival mostly in the context of the USA (with a brief mention of such churches elsewhere) where the megachurch movement is often assumed to have begun and perhaps the most significant nation when it comes to Christian modern religious revivals and 'awakenings'. It is these churches which are typical in the sense that they are of an Evangelicalism, Pentecostalism or Charismatic Renewal hue. While such churches embraced revival locally, as with megachurches generally (Wollschleger and Porter 2011), many have come to experience global significance. From one perspective revivalistic megachurches have a lot to offer the religious 'seeker'. They tend to be conservative in their theological character without being dogmatic, most dwell on personal salvation, but also frequently exhibited strong cultures of positive and motivational thinking with a stress on personal fulfilment and the attaining of personal aspirations. And, as Thomas (2009) has pointed out, new religious group are more involved with the spiritual market and the consumption of religious 'goods' and attractions, while more traditional religions seem to struggle in this globalised world. 
Pentecostalism is a significant religious movement which is not particularly new, being now over a century old, but in its various 'neo' forms is clearly capable of adapting to any circumstance or change which is likely to occur in both First and Third World countries (Poloma 2002). Its strength is that it is a world-wide religion linked by international ministry networks and seems to be successfully demonstrating that Christianity is still rigorous in different localised environments and a major competitor in the spiritual marketplace.

Pentecostalism, with its emphasis on revivalism and ministry, is conducive to the growth of many megachurches and their relevance is clearly by no means limited to the West. Jonathan James (a contributor to this volume), through his book A Moving Faith: Mega Churches Go South (2015), has charted the dynamic shift of Christianity to the South through neo-Pentecostal and Charismatic movements which constitute a global movement promising prosperity, healing, and empowerment. The centre of the faith has moved from North America and Europe to diverse places. This development has in part been expressed in the form of megachurches in as diverse as places as South Korea, Brazil, Peru, Ghana, Nigeria, Australia, India, and the Philippines, but also others which enjoin with Pentecostal/ Charismatic praxis and culture but do not necessarily refer to themselves as such. Kyle Murray (2012) largely concurs and argues that Charismatic and Pentecostal elements of global Christianity serve key roles in the production of free market hegemony within and between states, societies and markets across the world. While many of the institutions of these Christian social forces are fiercely decentralised, this popular global movement has converged on key elements of a shared conception of the world which links core, semi-peripheral and peripheral societies across national boundaries and class distinctions through networks of churches which the revivals from the 1990s onwards were encouraged to thrive.

Common to different contexts is the present mediatisation of religion in the spiritual marketplace results in its 'branding': a staging of religion according to the forms and patterns of commercialised media culture (Einstein 2007). In this respect Veronika Krönert and Andreas Hepp (2011) have explored the articulations of 'sacred worlds' around such specific 'brand symbols' to facilitate the mediation of religion, and how this impacts on media production and representation corresponds with religious individualisation in everyday life. These authors argue that in the context of an ongoing process of religious individualisation, 'brands' offer landmarks for individual religious questing and open up communicative spaces for personal spiritual experiences and the formulation of what Peter Berger called a sacred 'canopy' (Berger 1980). Religions are now forced to compete and communicate with each other in the infinite space of a mass-mediated public sphere as later revivals from the Toronto Blessing onwards indicates. And revival has its attraction in the spiritual marketplace 
for those who wish to be part of the rollercoaster of what is perceived as that which 'God is doing' today.

As briefly mentioned above, the approach taken by seeker-oriented megachurches to attract members often leads to a common belief that megachurches play down commitment and religious dogma, in favour of being 'seeker friendly' and aim at satisfying a consumerist cultural mentality. To engage with a theme discussed in various chapters in this volume, calling upon Thumma et al. (2005) work, megachurches are among the most successful churches today in attracting and retaining members. This suggests that they foster on-going commitment and involvement of their members, a view which would seem to concur with Iannaccone's (1994) insistence that successful churches tend to be 'strict' in the sense of charging a high price for membership and interest in the church. To this end megachurches make significant effort to construct pathways by which these individuals reconnect with God and in doing so they ask much of the people that become members. Such is the function of revival. Revivals spiritually rejuvenate church members but also help forge commitment and push them along on a wave of emotion, purpose and enthusiasm. Revivalism also has the purpose of winning new members, but it must not alienate the unsaved by initially being too demanding of them.

While no two megachurches are the same, most of have essential similarities. Certainly, there is the belief that it is necessary to return to the dynamism of the first century Church: its authenticity and zeal which revivalism suggests. Historically revivalism generally typically took sectarian form, those involved seeing their own emergence as signifying the return to New Testament principles - a claim often accompanied by fresh divine revelations forged within an eschatological vision of restoring the 'true' faith. This element is not entirely missing from megachurch thinking, but supplemented by a safe 'seeking' environment for potential comments. Neither is the kind of revivalism adopted entirely dogmatic. Bird and Thumma (2011) note a trend of megachurches turning away from distinctive theological segments within conservative Protestantism toward what they term a 'generic evangelicalism'. These trends combine to allow the megachurch enormous flexibility to respond to changes in their environment. Or, as Wellman et al. (2012) have suggested “This isn't just same-old, same-old. This is not like evangelical revivalism. It's a new, hybrid form of Christianity that's mutating and separate from all the traditional institutions with which we usually affiliate Christianity". In that sense Miller's assertion that they amount a new 'Reformation' may be an overstatement. But megachurches certainly constitute a fresh direction and will no doubt continue to be a vehicle for revivals of the future whatever shape these revivals may take. 


\section{References}

Anderson, A. 2004. An Introduction to Pentecostalism. Cambridge: Cambridge University Press.

Anderson, R.M. 1980. Vision of the Disinherited: The Making of American Pentecostalism. Oxford: Oxford University Press.

Berger, P. 1980. Heretical Imperative: Contemporary Possibilities of Religious Affirmation. New York: Doubleday.

Bird, W. and Thumma, S. 2011. "A New Decade of Megachurches. 2011 Profile of Large Attendance Churches in the United States." http://www.hartfordinstitute.org/ megachurch/New-Decade-of-Megachurches-2011Profile.pdf.

Brierly, M. 1991. “Christian” England: What the English Census of Reveals. London: MARC Europe.

Butler, J. 1990. Awash in a Sea of Faith: Christianizing the American People. Studies in Cultural History. Cambridge, MA: Harvard.

Cox, H. 1996. Fire From Heaven: The Rise of Pentecostal Spirituality and Re-Shaping of Religion in the Twenty-First Century. Reading, MA: Addison Wesley.

Einstein, M. 2007. Brands of Faith: Marketing Religion in a Commercial Age. New York: Routledge.

Finke, R. and Stark, R. 1992. The Churching of America, 1776-1990: Winners and Losers in Our Religious Economy. New Brunswick, NJ: Rutgers University Press.

Hartford Institute for Religious Research. "Database of Megachurches." Hirr.hartsem. $e d u$.

Hunt, S. 2009a. A History of the Charismatic Movement in Britain and the United States of America (Book 2). Lewiston, Queenston, Lampeter: The Edwin Mellen Press.

Hunt, S. 2oogb. "Charismatic Revival and Precarious Charisma: The Case of the Florida Healing 'Outpouring'. Australian Religious Studies Review. 22:1, 83-189.

Iannaccone, L. 1994. "Why Strict Churches Are Strong." American Journal of Sociology. 99:5, 1180-1211.

James, J. 2015. A Moving Faith: Mega Churches Go South. London: Sage Publications.

Knox, R. 1961. Enthusiasm: A History in the History of Religion with Special Reference to the 17th and 18th Centuries. Oxford: Oxford University Press.

Krönert, V. and Hepp, A. 2011. "Religious Media Events and Branding Religion." In M. Bailey and Guy Redden, eds, Mediating Faiths: Religion and Socio-Cultural Change in the Twenty-First Century. Farnham: Ashgate, 89-103.

Latham, S. 2003. “'God came from Teman': Revival and Contemporary Revivalism." In A. Walker and A. Aune, eds, On Revival: A Critical Examination: A Critical Examination. Carlisle: Paternoster Press.

Martin, D. 1990. Tongues of Fire: The Explosion of Pentecostalism in Latin America. Oxford: Blackwell. 
Mauss, A. and Perrin, R. 1992. "Saints and Seriousness." Review of Religious Research, 34, 176-178.

McBain, D. 1997. "Mainstream Charismatics: Some Observations of Baptist Renewal." In S. Hunt, ed, Charismatic Christianity: Sociological Perspectives. Basingstoke: McMillan (now Palgrave), 43-59.

McClymond, M. ed, 2004. Embodying the Spirit: New Perspectives on North American Revivalism. Baltimore, MD: The John Hopkins Press.

Miller, D. 1997. Reinventing American Protestantism: Christianity in the New Millennium. Berkeley, CA: University of California Press.

Murray, K. 2012. "Christian 'Renewal' and the Production of Global Free Market Hegemony." International Politics. 49:2, 260-276.

Poloma, M. 2002. "The Spirit Bade Me Go: Pentecostalism and Global Religion”. Department of Sociology, University of Akron, 1-18.

Poloma, M. 2003. Main Street Mystics: The Toronto Blessing and Reviving Pentecostalism. Walnut Creek, CA: Altimira Press.

Pousson, E. 1994. "A 'Great Century' of Pentecostal/Charismatic Renewal and Missions", Pneuma: The Journal of the Society for Pentecostal Studies. 16:1, Spring, 81-100.

Richter, P. 1995. “'God is Not a Gentleman!': The Sociology of the Toronto Blessing.” In S. Porter and P. Richter, eds, The Toronto Blessing or Is it? London: Darton, Longman $\&$ Todd, $4-36$.

Tellefsen, A. and Bromley, D. nd. Brownsville Revival. World Religions and Spirituality. Virginia Commonwealth University. https://wrldrels.org/2016/10/08/brownsville -revival/

Thomas, P. 20og. "Selling God/Saving Souls: Religious Commodities, Spiritual Markets and the Media." Global Media and Communication, 5:1, 57-76.

Thumma, S. and Bird, W. 2015. "Recent Shifts in America's Largest Protestant Churches: Megachurches 2015 Report." Hartford Institute for Religion Research. At http://hirr .hartsem.edu/megachurch/megachurches_research.html. Accessed 10/07/17.

Thumma, S. and Travis, D. 2007. Beyond Megachurch Myths. San Francisco: John Wiley.

Thumma, S., Travis, D. and W. Bird 2005. Megachurches Today 2005: Summary of Research Findings. http://hirr.hartsem.edu/megachurch/megastoday2005_summary report.html.

Walker, A. 1997. "Thoroughly Modern: Sociological Reflections on the Charismatic Movement from the End of the Twentieth Century." In S. Hunt, ed, Charismatic Christianity: Sociological Perspectives. Basingstoke: McMillan (now Palgrave), $17-42$.

Walker, A. and Aune, A. eds, 2003. On Revival: A Critical Examination: A Critical Examination. Carlisle: Paternoster Press. 
Ward, P. 2003. "Selling Revival as Worship." In A. Walker and A. Aune, eds, On Revival: A Critical Examination. Carlisle: Paternoster Press.

Wellman, J., Corcoran, K. and K. Stockly-Meyerdirk 2012. “God is Like a Drug': Explaining Interaction Ritual Chains in American Megachurches." Paper given at the 107th Annual Meeting of the American Sociological Association.

Wollschleger, J. and Porter, J. 2011. “A 'WalMartization' of Religion? The Ecological Impact of Megachurches on the Local and Extra-Local Religious Economy." Review of Religious Research. 53:3, 279. 